\title{
Vegetation and water of lowland spring-wells in Po Plain (Northern Italy): ecological features and management proposals
}

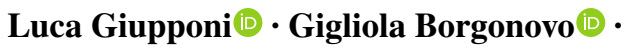 \\ Valeria Leoni - Marco Zuccolo (D) \\ Gian Battista Bischetti (D)
}

Received: 6 October 2021 / Accepted: 3 February 2022 / Published online: 11 February 2022

(C) The Author(s) 2022

\begin{abstract}
Spring-wells (lowland springs, "fontanili") are elements of Po Plain (Northern Italy) with ecological and historical importance. There, springwater flows naturally and rises to the surface at a relatively constant temperature, generating unique ecosystems dependent on the groundwater outflow. Despite their importance, they are endangered by degradation processes as the expansion of urban areas and/or the intensification of agriculture, very marked in Po Plain. This research describes four spring-wells of Po Plain from a botanical and ecological perspective through phytosociological relevés and different ecological indexes. Water chemical-physical features are also considered $(\mathrm{pH}$, temperature and ammonium
\end{abstract}

Supplementary Information The online version contains supplementary material available at https://doi. org/10.1007/s11273-022-09865-5.

L. Giupponi $(\bowtie) \cdot$ V. Leoni $\cdot$ M. Zuccolo

Centre of Applied Studies for the Sustainable Management and Protection of Mountain Areas - C.R.C. Ge.S.Di.Mont., University of Milan, Via Morino 8, 25048 Edolo, BS, Italy e-mail: luca.giupponi@unimi.it

L. Giupponi · G. B. Bischetti

Department of Agricultural and Environmental Sciences

- Production, Landscape and Agroenergy, University

of Milan, Via Celoria 2, 20133 Milan, Italy

G. Borgonovo

Department of Food, Environmental and Nutritional

Sciences, University of Milan, Via Celoria 2, 20133 Milan, Italy ion, nitrite, nitrate, orthophosphate, chloride and organic matters contents). Plant communities of the spring-well beds show a low number of species $(5.8 \pm 2.9)$ but also no exotic species while the vegetation of the banks has a high number of species $(32.4 \pm 9.8)$ but several of them are exotic/ornamental. The low value of the Ecological Index of Maturity of the vegetation of the banks $(\mathrm{EIM}=4.4 \pm 1.5)$ indicate disturbances, however moderate compared to the surrounding corn fields (EIM $\sim 0)$. All the water samples has high ammonium content $(>0.50 \mathrm{ppm})$, the water of the spring-well B results the most polluted and both algae and Callitriche obtusangula (rare native species) grow largely in it, while spring-well $\mathrm{C}$ has less phosphates and more nitrite and is marked by Equisetum telmateia. Management proposals to protect and enhance the studied spring-wells, as the gradual removal of exotic species and the planting of native species, are discussed.

Keywords Ecological index of maturity ·

Wetlands · Groundwater-dependent ecosystems ·

Exotic species · Lowland springs (fontanili) · Nature conservation

\section{Introduction}

Wetlands play an important role in providing ecosystem goods and services to human society. However, the neglection of their importance intensified their 
loss due to the widespread conversion of wetlands because of shortages of land that is suitable for agriculture and urban settlement (He et al. 2015). They are very often environments rich in species, local climate regulators as well as elements that enrich the landscape and the historical-cultural heritage of the territory in which they are located (Ramsar Convention Bureau 2001; Mitra et al. 2003). Although they provide important services, wetlands are declining faster than any other ecosystems (MEA 2005) and this phenomenon affects the whole Globe, in particular those territories where the expansion of urban areas and agricultural activities is more marked $(\mathrm{Hu}$ et al. 2017). In fact, recent studies estimated that at least $33 \%$ of global wetlands has been lost since 2009 (Hu et al. 2017) and 64-71\% since the early 1900 (Davidson 2014), and that this loss is mainly due to land conversion as well as to climate change (Lin and Yu 2018).

The Po Plain is the largest plain in Italy and in southern Europe $\left(47.800 \mathrm{~km}^{2}\right)$. It is bordered to the north and west from the Alps, to the south from the Apennines and to the east from the Adriatic Sea. Today much of the territory of Po Plain is farmed according to intensive farming methods and occupied by large, urbanized areas that grew rapidly during the last century and are still in expansion. Considering the geological, pedological and environmental characteristics, Po Plain is divided into two main areas: the "high plain" and the "low plain" (Martinis et al. 1976; Andreis 2002). The "high plain" is at the base of the slopes of the Alps and the Apennines (over 100-150 $\mathrm{m}$ a.s.1.) and is characterized by very permeable soils whose particles size consists mainly of coarse elements (stones, gravel, and sand). In the "high plain", rainwater penetrates the soil in depth until it reaches waterproof rocks/sediments on which it flows and then resurfaces at lower altitudes (100-80 m a.s.1.), giving rise to resurgences (Toniolo 1933; Minelli et al. 2002; De Luca et al. 2014). The resurgences are located along a large part of Po Plain forming a belt from west to east parallel to the foothills (about $800 \mathrm{~km}$ long and $25 \mathrm{~km}$ wide) which is known as the "resurgence belt" and which delimits the "high plain" from the "low plain" (Martinis et al. 1976; De Luca et al. 2014). The soils of the "low plain" have finer and impermeable particles (silt and clay) that allow the water to stagnate and generate swamps (covered by hygrophilous forests) which, however, were reclaimed by man (from the Roman age up to the last century) to promote agriculture (Frattini 2008; De Luca et al. 2014). Human work transformed the resurgences of Po Plain into spring-wells (lowland springs, "fontanili") (Corbetta 1969; De Luca et al. 2014), concentrating their points of emergence. The spring-wells were obtained by enlarging the natural valleys in the land, encouraging the water to surface, forming a more or less rounded "head", that can collect more springs. The water collected is channelled into a canal or "central axis" of the watercourse (Corbetta 1969; De Luca et al. 2014).

The spring-wells are groundwater-dependent ecosystems (GDEs) defined as "ecosystems for which current composition, structure and function are reliant on a supply of groundwater" (Kløve et al. 2011). Among GDEs, spring-wells are unique ecosystems dependent on the groundwater outflow (EC 2015). The spring-wells provide water with relatively constant temperature $\left(8-15^{\circ} \mathrm{C}\right)$ (Fumagalli et al. 2017): seasonal variations affect the water temperature with a delay of 2-4 months, making the coldest period in April and the warmest in October, creating particular environments where rare plants and animals of community interest can live (Bertolani Marchetti 1959; Pisoni and Valle 1992; Viaroli et al. 2003; De Luca et al. 2005; Frattini 2008; Alessandrini et al. 2011; Bischetti et al. 2012). For this reason, the spring-wells are included in the Habitat Directive of the European Union (EC 1992) but most of them are currently at risk due to degradation processes happened mainly in the Sixties (Bischetti et al. 2012).

A large part of Po Plain falls within the Lombardy region which is one of the largest $\left(23.800 \mathrm{~km}^{2}\right)$, most anthropized (10 million people) and productive regions of Italy and of the Alpine macro-Region (EUSALP). In the plains of Lombardy there are 1.160 (Fumagalli et al. 2017) spring-wells that were not destroyed by the expansion of urban areas and/ or intensification of agricultural practices. Despite Fumagalli et al. (2017) tried to evaluate all the springwells of Lombardy using a set of simple indicators to evaluate watering, ecological and recreational function, only for a few of these scientific studies relating to their biotic and abiotic components of the ecosystem were carried out (Piazzoli Perroni 1959; Albergoni et al. 1977; Bertuletti 1992; Cavagnis and Orsini 1992; Pisoni and Valle 1992; D'Auria and Zavagno 2005; Frattini 2008; Balestrini et al. 2016, 2021). 
This research aims at analysing the vegetation (from a floristic and ecological point of view) of four spring-wells in the plain of the province of Brescia in order to provide management practices useful to preserve, restore and enhance these wetlands. In particular, phytosociological relevés of the vegetation of the "heads" of the spring-wells were carried out and a system of ecological indices (Taffetani and Rismondo 2009; Rismondo et al. 2011; Giupponi et al. 2015) was applied in order to highlight elements of biological value and evaluate the state of conservation/degradation of these environments. Furthermore, the chemical-physical characteristics of the waters from the spring-wells were analysed to assess their level of pollution and highlight any relationships with the presence/absence of hygrophilous plants.

\section{Materials and methods}

Study areas

The four springs considered in this research are in Po Plain within the province of Brescia (Lombardy region, Italy) (Table 1, Fig. 1). Some of them (A and C) are surrounded by maize fields (corn cultivated according to intensive farming techniques) while others (B and D) are in urban areas and are adjacent to houses/gardens and/or roads. At the edge of some spring-wells there are recreational areas where various exotic/ornamental species were planted such as: Eryobotrya japonica, Aesculus hippocastanum, Hibiscus spp., Rosa spp., Musa spp. Since 2012 the ordinary management work (cleaning the springwell riverbed, cutting dangerous trees, etc.) of this
Table 1 Geographic data of the four spring-wells

\begin{tabular}{lllcc}
\hline $\begin{array}{l}\text { Spring-well identifi- } \\
\text { cation code }\end{array}$ & Municipality & Latitude N & Longitude E & $\begin{array}{l}\text { Elevation } \\
\text { (m a.s.l.) }\end{array}$ \\
\hline A & Castel Mella (BS) & $45^{\circ} 29^{\prime} 23.9^{\prime \prime}$ & $10^{\circ} 08^{\prime} 03.8^{\prime \prime}$ & 100 \\
B & Brandico (BS) & $45^{\circ} 27^{\prime} 09.2^{\prime \prime}$ & $10^{\circ} 03^{\prime} 03.9^{\prime \prime}$ & 96 \\
C & Lograto (BS) & $45^{\circ} 28^{\prime} 39.8^{\prime \prime}$ & $10^{\circ} 03^{\prime} 41.7^{\prime \prime}$ & 106 \\
D & Trenzano (BS) & $45^{\circ} 28^{\prime} 41.2^{\prime \prime}$ & $10^{\circ} 01^{\prime} 15.1^{\prime \prime}$ & 104 \\
\hline
\end{tabular}

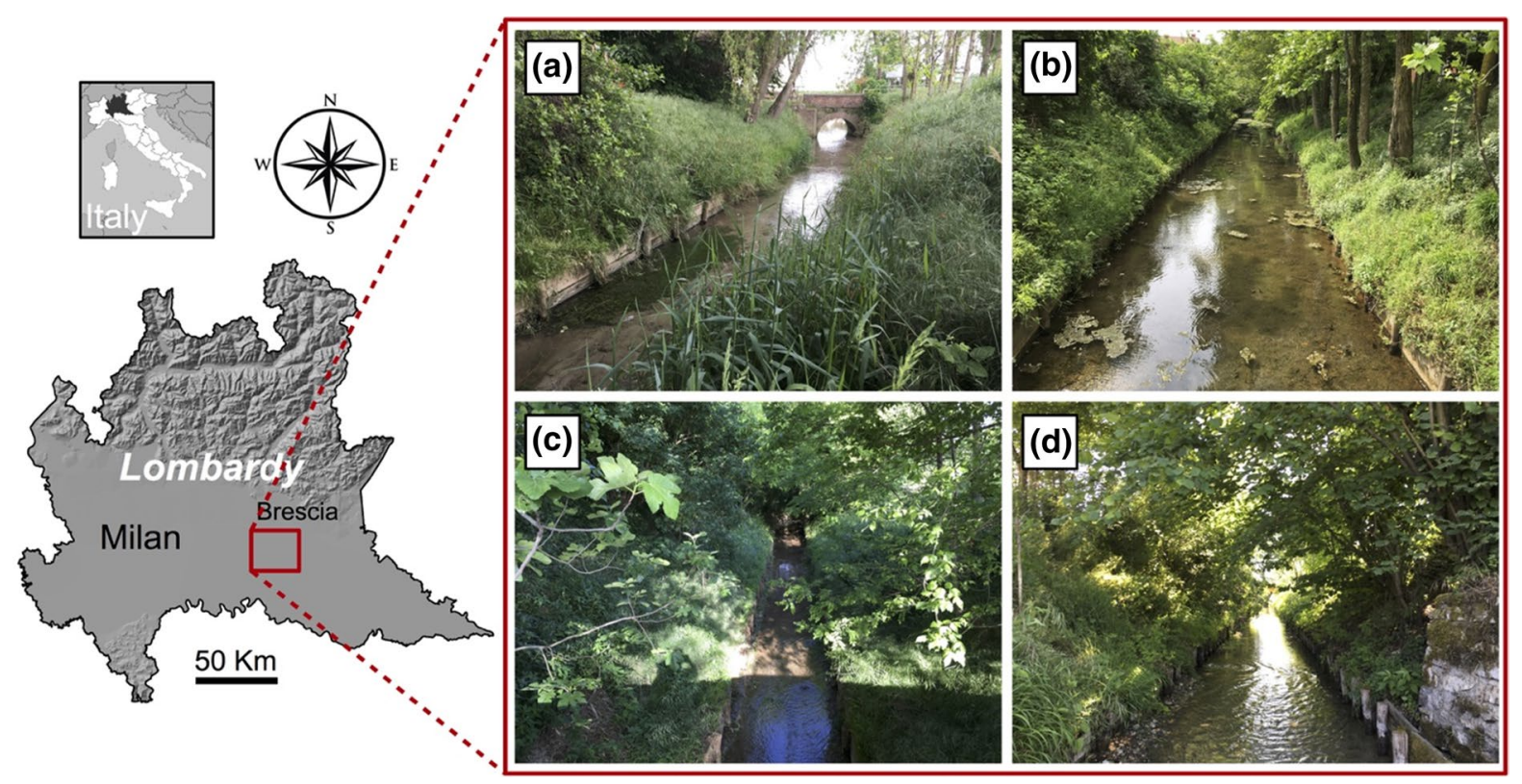

Fig. 1 The study area where the four spring-wells are located. The code of the spring-wells (A, B, C and $\mathbf{D})$ is the same reported in Table 1 
spring-wells has been carried out by the Oglio Mella Reclamation Consortium.

The study area is enclosed in the temperate continental bioclimatic zone (Rivas-Martínez et al. 2004) and in the Po Plain ecoregional section (Po Plain province, Temperate division) (Blasi et al. 2014). This ecoregional section is $49,800 \mathrm{~km}^{2}$ wide, and it is constituted by Po Plain territories with similar climatic features, physiography (lithomorphology is characterised by the clastic plain of the Po Plain foredeep) and potential natural vegetation (plain forests of Quercus robur and Carpinus betulus and riparian forests close to the streams/rivers) (Del Favero 2002; Verde et al. 2010; Blasi et al. 2014). It includes a considerable amount of agricultural areas (81\%) with extensive artificial surfaces (10\%) and few natural and semi-natural areas (6\%) (Blasi et al. 2014). Annual precipitation ranges from $580 \mathrm{~mm}$ up to $1350 \mathrm{~mm}$ (with winter minimum) while the mean annual temperature ranges between $11^{\circ} \mathrm{C}$ and $14{ }^{\circ} \mathrm{C}$.

\section{Vegetation analysis}

Data on the current vegetation of the four springwells were collected by performing 20 phytosociological relevés according to the method of Braun-Blanquet (1964) and using his conventional abundance/ dominance scale (r, rare species in the relevé; + , coverage $<1 \%$; 1 , coverage $1-5 \%$; 2 , coverage $5-25 \%$; 3 , coverage $25-50 \%$; 4 , coverage $50-75 \%$; 5 , coverage 75-100\%). In detail, 5 relevés for each spring-well "head" were performed: one in the bed of spring-well (zone I) and four in the banks/edges (zone II) (Fig. 2). In addition to the relevés of the spring-well, 5 phytosociological relevés were carried out in the maize fields adjacent to the spring-well $\mathrm{A}$ and $\mathrm{C}$ in order to compare the vegetation of the spring-well and of the most common farming system of Po Plain.

The relevés were performed during summer months (June-July) of 2020 and an area of $30 \mathrm{~m}^{2}$ was studied for the vegetation of the banks/edges and that of the bed of spring-well, while for the maize fields an area of $25 \mathrm{~m}^{2}(5 \times 5 \mathrm{~m})$ was examined. Plant species (tracheophytes) were identified using the keys of Pignatti (2017). The abundance (rarity) in Lombardy of each species found in the spring-wells was defined following Martini et al. (2012). Biological spectrum of flora list was elaborated considering the life form of each species. Life form of the plants according to Raunkiaer's (1934) categories (chamaephytes - Ch; geophytes - G; hemicryptophytes- $\mathrm{H}$; hydrophytes - $\mathrm{I}$; nano-phanerophytes-NP; phanerophytes-P; therophytes-T) follows Pignatti (2017), and it was checked on field.

The data of the relevés were arranged in a matrix (relevés x species) where abundance/dominance indices of Braun-Blanquet were converted into the percentage of coverage in accordance with Canullo et al. (2012) (r, $0.01 \% ;+, 0.5 \% ; 1,3.0 \% ; 2,15.0 \% ; 3,37.5 \%$; $4,62.5 \% ; 5,87.5 \%$.) to perform statistical analysis. A hierarchical cluster analysis and detrended correspondence analysis (DCA) were performed to identify floristic similarities/differences among the relevés. Cluster analysis was performed using the Unweighted Pair Group Method with Arithmetic mean method (UPGMA) and the chord distance coefficient (Legendre and Gallagher 2001). The optimal number of clusters (the smallest number of clusters which account for the largest amount of variation in the data) was assessed based on the "elbow" method that consists of plotting the explained variation as a function of the number of clusters and picking the elbow of the curve as the number of clusters to use. Statistical analysis (cluster analysis and DCA) was performed using $\mathrm{R}$ 3.6.1 software (R Development Core Team 2021).

The ecological index of maturity (EIM) (Giupponi et al. 2015) was calculated for each type of vegetation returned by cluster analysis. The EIM measures the level of disturbance affecting a plant community considering phytosociological class, chorotype, and coverage of each species present, and was calculated according to the following formula (Giupponi et al. 2015, 2017a):

$\mathrm{EIM}=\frac{\mathrm{IM}\left[\left(1-\frac{\mathrm{IE}}{100}\right)+\frac{\mathrm{IL}}{100}\right]}{1+\frac{\mathrm{IL}}{100}}$

where IM is the index of maturity, IE is the index of the exotic component and IL is the index of the endemic component. EIM values can range from 0 (high vegetation disturbance) to 9 (undisturbed vegetation).

The IM provides a measure of the actual stage of maturity of a plant community and is calculated as follows Taffetani and Rismondo (2009):

$\mathrm{IM}=\frac{\sum_{i=1}^{n}\left(c_{i} m\right)}{C}$ 


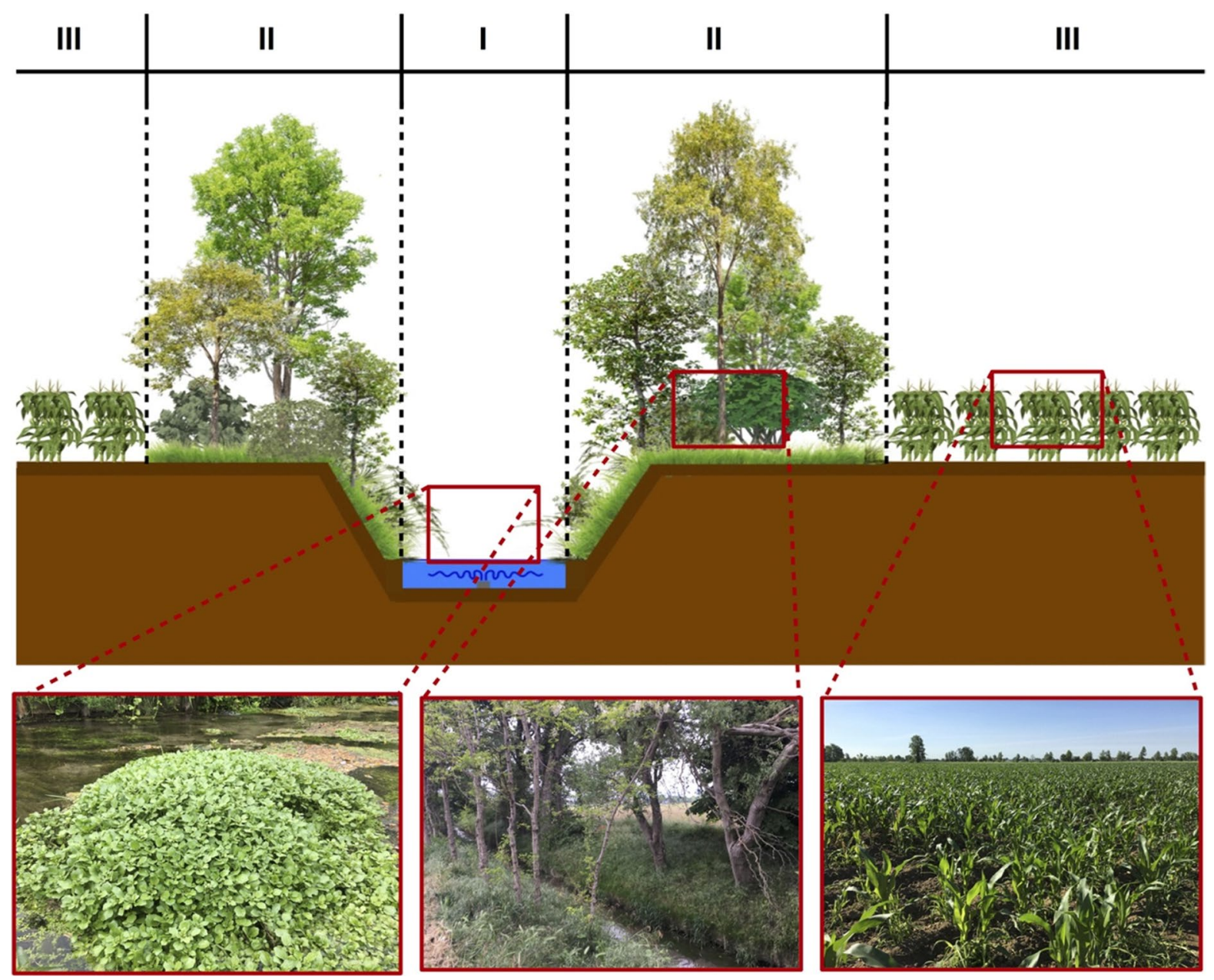

Fig. 2 Structure of a spring-well and the three zones where the phytosociological relevés were carried out: I, bed of the spring-well; II, banks and edges; III, maize fields close to the spring-well

where $c_{i}$ is the coverage value of each single species, $i(i=1,2, \ldots, n)$ is the number of species, $m$ is the coefficient of maturity of the phytosociological class to which each species belongs, $C$ is the total coverage value obtained by summing the values of $c$ for all the species present. The coefficient of maturity $(m)$ is the value assigned to the main phytosociological classes of European vegetation according to the physiognomic-structural, synecological characteristics and the syndynamic role of the vegetation of each class Taffetani and Rismondo (2009); Rismondo et al. (2011); Giupponi et al. 2017a) (Table S1).

The IE provides the percentage of exotic species of a plant community considering exotic species coverage compared to total coverage while IL gives the percentage of endemic species (Giupponi et al. 2015). The IE measures the degree of exotic contamination and artificiality of the vegetation in relation to human pressure. National and European bibliographic sources were consulted for the attribution of phytosociological class to each species (Mucina et al. 1993; Del Favero 2002; Ubaldi 2008a, b; Landolt et al. 2010; Biondi and Blasi 2015). Syntaxonomic nomenclature follows that of the Vegetation Prodrome of Italy (Biondi et al. 2014; Biondi and Blasi 2015).

\section{Water analysis}

Three water samples of $1 \mathrm{~L}$ were collected in each spring-wells in three different months: May, July 
and September 2020. The water samples were collected at the "head" of the spring-wells after measuring the water temperature with a digital thermometer (Checktemp $^{\circledR} 1$-HI98509 Hanna Instruments). The 12 water samples were stored in dark bottles placed in in a thermostated refrigerator (AL B3RT0, Tambu Instruments) at a temperature of $4{ }^{\circ} \mathrm{C}$ until their chemical analysis in order to avoid the alteration of their chemical characteristics. The ammonium ion, nitrite, nitrate, orthophosphate and chloride contents were evaluated for each water sample using a spectrophotometric method. In detail, the ammonium ion content in the water was assessed using Nessler's reagent while the nitrite was quantified using the Griess reagent (CNR-IRSA 2003; Kruse and Mellon 1953). The nitrate content of each water sample was obtained according to Tartari and Mosello (1997) while the water-soluble orthophosphate ion was determined in accordance with Menzel and Corwin (1965). The determination of chloride was carried out by the Mohr method (Vollenweider 1962). A digital $\mathrm{pH}$ meter (BASIC, Denver Instrument) was used to measure the $\mathrm{pH}$ of each water sample and the concentration of oxygen in the water (indicator of organic matters) was determined using permanganate value method (Kubel method) (Heukelekian et al. 1954). Each chemical analysis was performed in triplicate.

The results of the chemical-physical analyses of the water and the data of the relevés carried out in the riverbeds of the spring-wells were analysed using canonical correspondence analysis (CCA) to highlight the most important variables that differentiate the spring-wells and the presence/absence of species. CCA was performed using "vegan" package (Oksanen et al. 2019) of R (R Development Core Team 2021).

\section{Results}

Flora and vegetation

During the study 141 species were identified (Table S2). Most of them (73\%) are perennial terrestrial plants (hemicriptophytes, phanerophytes, geophytes and nano-phanerophytes) while the therophytes (annual/ephemeral plants) are $26 \%$ of the biological spectrum (Fig. 3a). The latter are mostly species of Stellarietea mediae phytosociological class, typical of urban/anthropic environments (such as: Anisantha sterilis, Hordeum murinum, Lamium purpureum and Avena fatua). The aquatic plants (hydrophytes), that are mainly located along the bed of the spring-wells, make up $1 \%$ of the flora list. $20 \%$ of the identified species are exotic (Fig. 3b). Most of these are ornamental/garden plants not very common or rare in the natural environments of Lombardy (Nandina domestica, Spirea chamaedryfolia, Iris orientalis, Oxalis articulata etc.) but there are also naturalized and invasive species very common in northern Italy such as Robinia pseudoacacia, Morus alba, Ailanthus altissima, Ambrosia artemisiifolia and Erigeron canadensis (Fig. 3c). No endemic species were identified while some uncommon or rare native species of Lombardy were found, such as Callitriche obtusangula (aquatic species presents in A, B and D spring-wells) (Fig. 3d), Prunus domestica, Carex riparia, Poa palustris, Lemna minor and Helosciadium nodiflorum.

The dendrogram resulting from the cluster analysis (Fig. 4a) shows three groups (clusters) of relevés corresponding to the three different vegetation types present in the three zones were the relevés were carried out:

- I, hydrophilic vegetation of the bed of springwells: characterized by aquatic/helophytic species of Lemnetea monoris, Potametea pectinati and Phragmito australis-Magnocaricetea elatae phytosociological classes (Table S2);

- II, vegetation of the banks/edges: characterized by ruderal species of Stellarietea mediae and Artemisietea vulgaris, and species of shrublands (Rhamno catharticae-Prunetea spinosae and Robinietea), meadows (Molinio-Arrhenatheretea), woods (Querco roboris-Fagetea sylvaticae and Salici purpureaePopuletea nigrae) and marsh/lacustrine environments (Phragmito australis-Magnocaricetea elatae) (Table S2);

- III, vegetation of maize fields: characterized by Zea mays and some cosmopolitan weeds including Cynodon dactylon and Sorghum halepense (Table S2).

DCA biplot (Fig. 4c) confirms the results of the cluster analysis that does not show floristic 

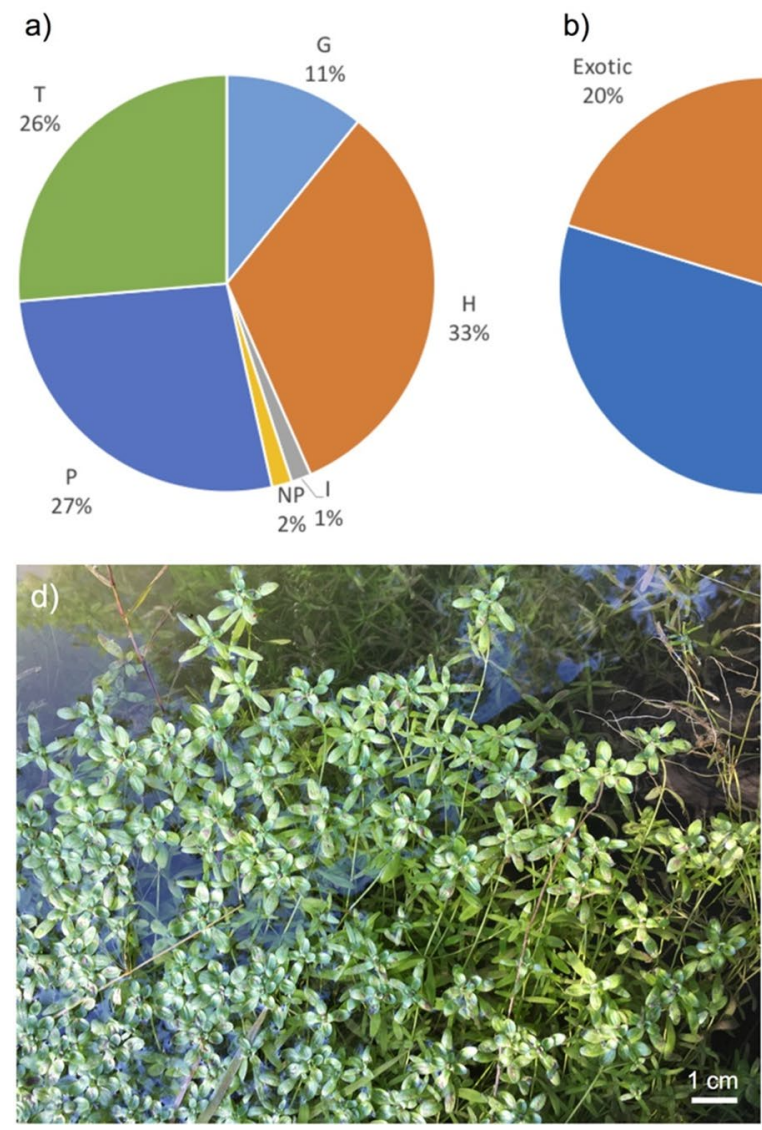

Fig. 3 Biological spectrum of spring-wells flora (a), percentage of exotic and native species (b) and abundance definition of the species found in the spring-wells referring to Lombardy region according to Martini et al. (2012) (c). The photographs show Callitriche obtusangula (rare native species) (d) and

differences among the banks/edges vegetation of the four spring-wells.

Figure 5 shows the ecological characteristics of the three types of vegetation. The plant community of the spring-well bed (I) has a low number of species but has no exotic species, so the values of IM and EIM are the same. The vegetation of the banks, instead, has a high number of species but several of them are exotic/ornamental. The EIM value of vegetation II is lower than that of IM and this indicates disturbances affecting this plant community. However, these disturbances are moderately low if compared to those affecting corn fields (III) where there is a dominant exotic species (Zea mays) and ruderal weeds able to survive in disturbed and/or degraded environments.
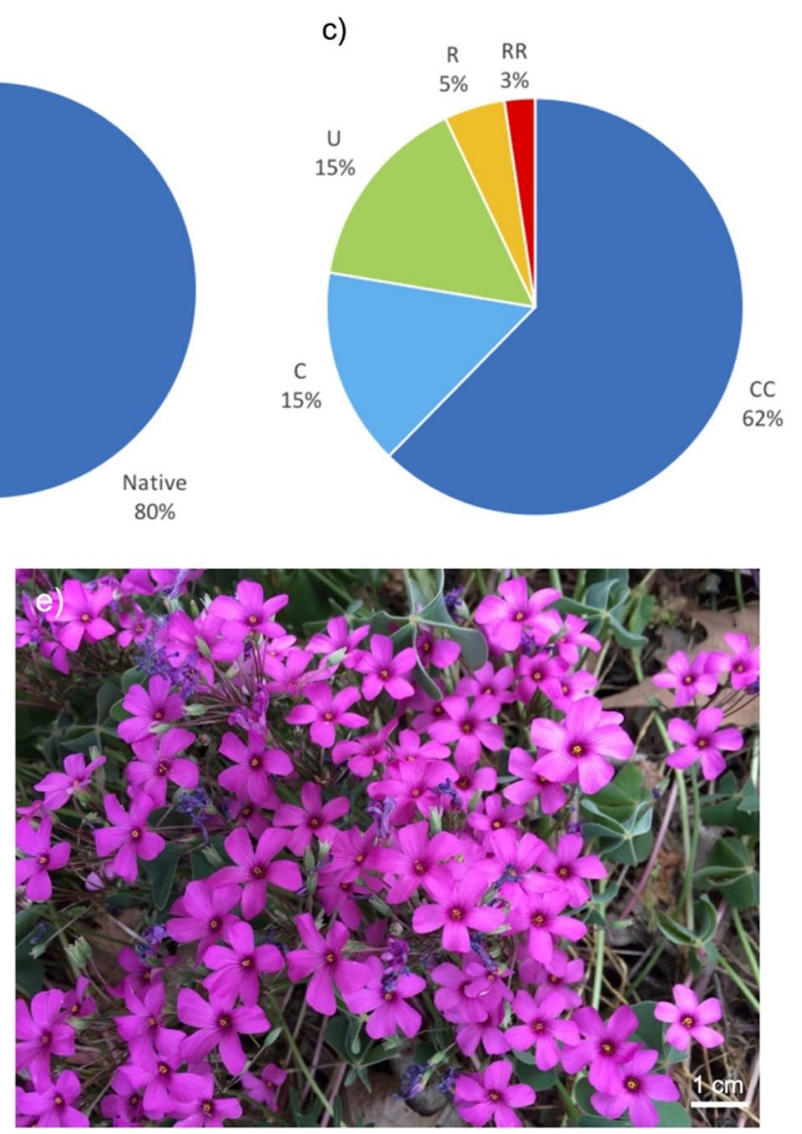

Oxalis articulata (uncommon exotic species) (e). Key: G, geophytes; T, therophytes; H, hemicryptophytes; P, phanerophytes; NP, nano-phanerophytes; I, hydrophytes; RR, very rare in Lombardy; R, rare; $\mathrm{U}$, uncommon; $\mathrm{C}$, common; CC, very common

Water

Table 2 shows the chemical-physical features of the spring-wells water. All the water samples have high (and similar) ammonium content, over the Italian legal quality thresholds for groundwater. The water of the spring-well B results the most polluted. In fact, it has high concentration of orthophosphate and organic substance (concentration of oxygen due to the presence of organic oxidisable substance) in addition to the high concentration of ammonium. Moreover, the water of $\mathrm{B}$ has a higher concentration of nitrate but within the limit of Italian Law 152/2006 of the quality of groundwater (Table 2). The oxygen concentration of water in spring-well B was over the threshold only in May (5.37 ppm) while the water of the 

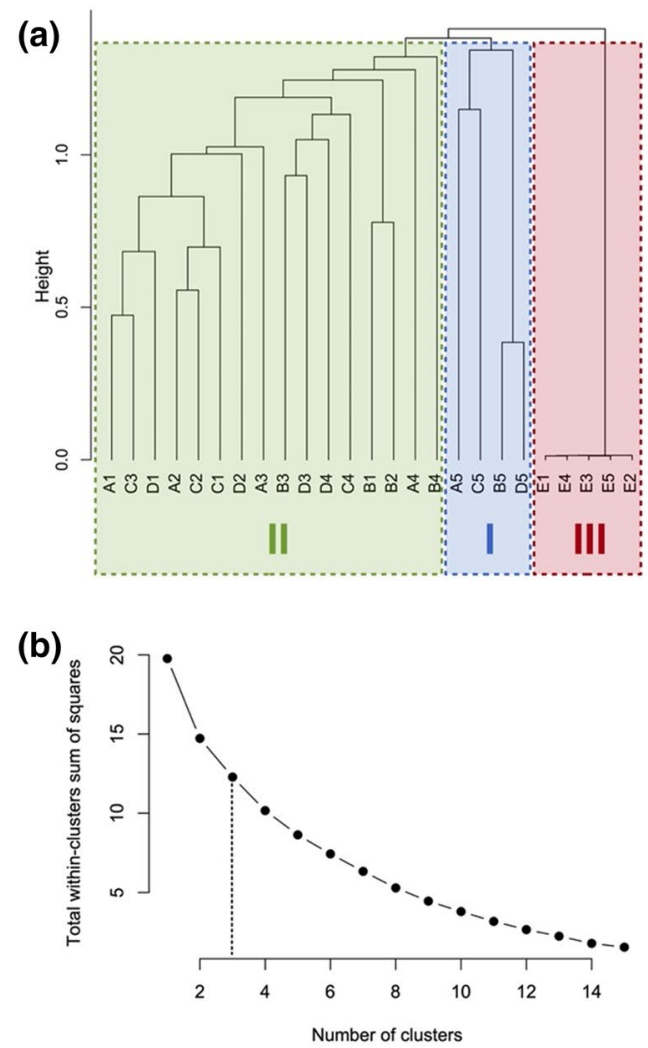

Fig. 4 Dendrogram of the relevés (capital letters indicate the code of the spring-well) (a), distribution of total within-clusters sum of squares by number of relevé groups distinguished via hierarchical clustering (b), DCA biplot (c) and variance

spring-well $\mathrm{C}$ exceeded the threshold for nitrite only in September $(0.70 \mathrm{ppm})$ and the water of the springwell A had exceeded the threshold for orthophosphate (Italian Law 152/1999) only in July (1.18 ppm). The chloride and nitrate values of all spring-wells are below the quality thresholds for groundwater. The mean temperature of the water of the well-springs is $16.16 \pm 0.41{ }^{\circ} \mathrm{C}$.

The results returned by CCA are shown in Fig. 6. The biplot shows a main ecological gradient along the first axis (CCA1) which explains most of the variance in the dataset. In particular, along the CCA1 ammonium and nitrite in water decrease while nitrate, orthophosphate and organic substance increase. The water of spring-well B is the most polluted and both algae (indicators of eutrophic water) and Callitriche obtusangula are abundantly present in it (Table S2). The same plants also grow in the bed of $\mathrm{A}$ and $\mathrm{D}$ spring-wells but with less
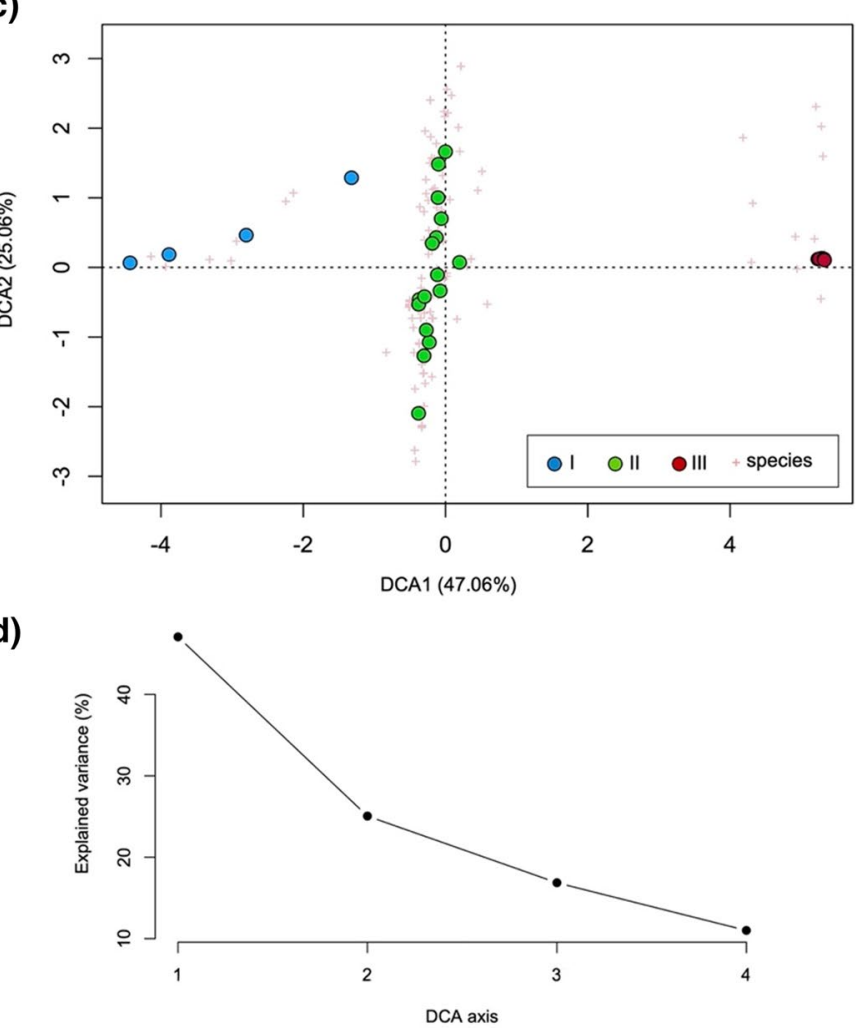

explained by the first four DCA axes (d). Key: I, relevés performed in the spring-wells bed; II, relevés of the banks/edges vegetation; III, relevés of the maize fields

coverage values (Table S2). Spring-well C differs from the others for water with less phosphates and more nitrite, moreover in its bed (and on its banks) Equisetum telmateia is abundant (Fig. 6, Table S2). Helosciadium nodiflorum is also abundant in $\mathrm{C}$ but still present, with lesser coverage, also in $\mathrm{A}$ and $\mathrm{D}$ while it is absent in B. The spring-well A is characterized by some hygrophilous species that are little or not present in the other study sites, such as: Poa palustris, Hypericum tetrapterum, Phalaroides arundinacea and Lythrum salicaria. Agrostis stolonifera is the only species found in all the beds of the spring-wells considered in this research. 

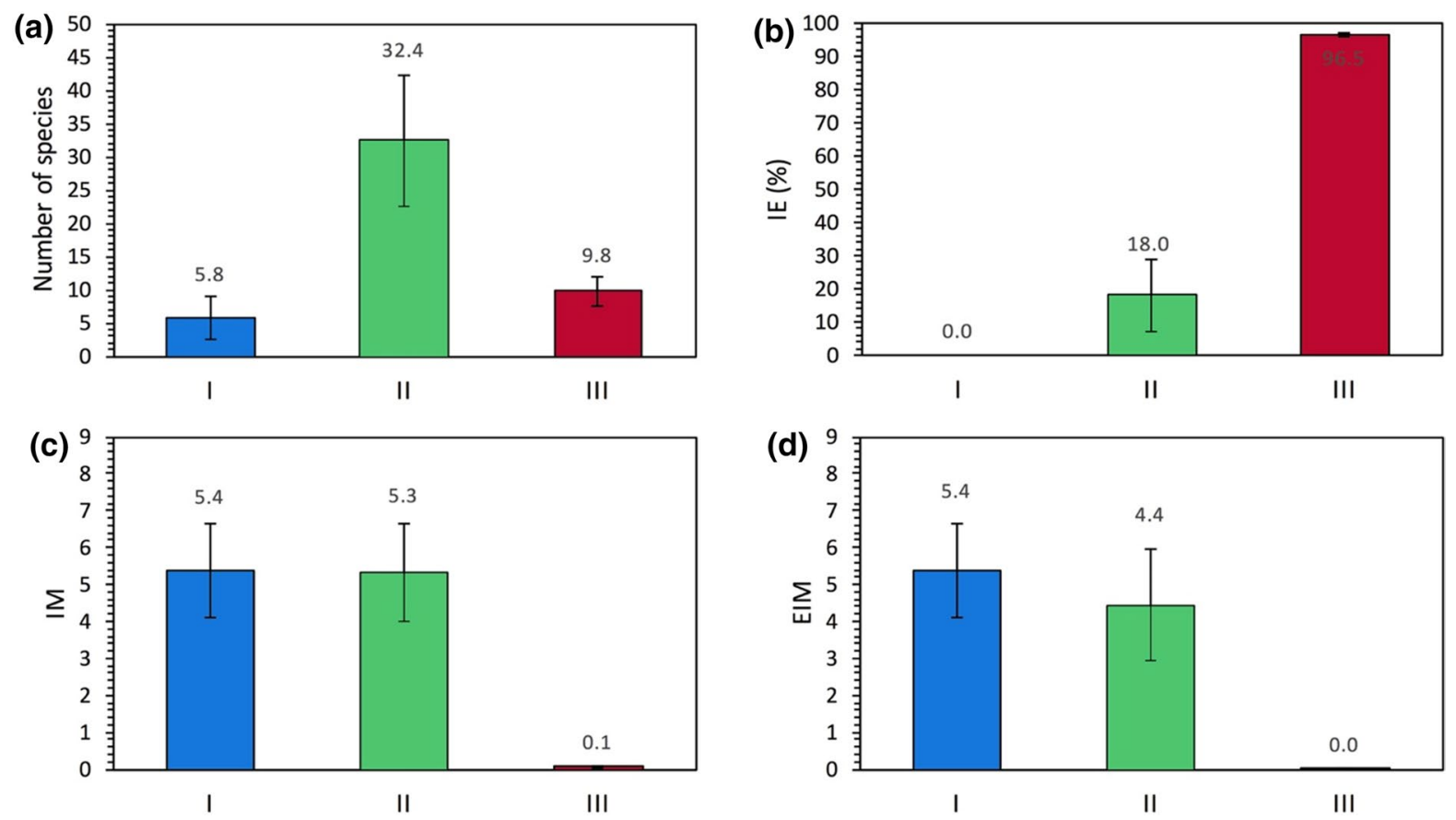

Fig. 5 Number of species (a) and values of index of exotic component (IE) (b), index of maturity (IM) (c) and ecological index of maturity (EIM) (d) of the three types of vegetation: I,

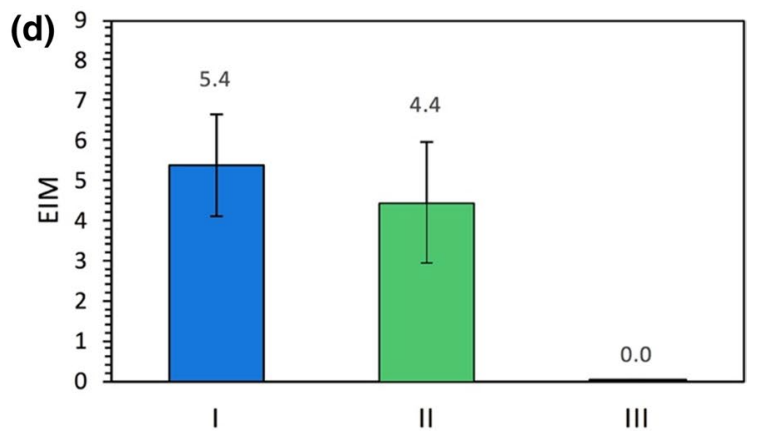

vegetation of the spring-wells bed; II, vegetation of the banks/ edges; III, maize fields

Table 2 Chemical-physical characteristics of the water of the four spring-wells (A, B, C and D) compared with the legal thresholds of the quality of groundwater (Italian Law 152/2006)

\begin{tabular}{|c|c|c|c|c|c|c|c|c|c|}
\hline \multirow[t]{2}{*}{ Parameter } & \multicolumn{2}{|l|}{ A } & \multicolumn{2}{|l|}{ B } & \multicolumn{2}{|l|}{$\mathrm{C}$} & \multicolumn{2}{|l|}{ D } & \multirow[t]{2}{*}{ Threshold value } \\
\hline & Mean & SE & Mean & SE & Mean & SE & Mean & SE & \\
\hline Temperature $\left({ }^{\circ} \mathrm{C}\right)$ & 16.30 & 0.36 & 15.80 & 0.87 & 15.87 & 0.31 & 16.67 & 0.31 & - \\
\hline $\mathrm{pH}$ & 7.21 & 0.05 & 7.20 & 0.05 & 7.23 & 0.00 & 7.35 & 0.09 & $6.5-9.5$ \\
\hline $\mathrm{NH}_{4}^{+}(\mathrm{ppm})$ & $0.56 * *$ & 0.00 & $0.54 * *$ & 0.01 & $0.57 * *$ & 0.00 & $0.55^{* *}$ & 0.01 & 0.50 \\
\hline $\mathrm{NO}_{3}{ }^{-}(\mathrm{ppm})$ & 2.24 & 1.88 & 5.13 & 1.88 & 0.58 & 0.45 & 1.54 & 0.57 & 50.00 \\
\hline $\mathrm{NO}_{2}^{-}(\mathrm{ppm})$ & 0.05 & 0.03 & 0.05 & 0.03 & $0.29 *$ & 0.36 & 0.01 & 0.00 & 0.50 \\
\hline $\mathrm{PO}_{4}{ }^{3-}(\mathrm{ppm})$ & $0.65^{*}$ & 0.46 & $0.75 * *$ & 0.15 & 0.35 & 0.09 & 0.42 & 0.11 & 0.70 \\
\hline $\mathrm{Cl}^{-}(\mathrm{ppm})$ & 25.41 & 1.02 & 20.09 & 1.10 & 21.27 & 1.06 & 17.14 & 1.07 & 250.00 \\
\hline Kubel oxidation $\left(\mathrm{O}_{2} \mathrm{ppm}\right)$ & 1.94 & 0.92 & $2.21 *$ & 2.73 & 0.67 & 0.14 & 0.52 & 0.05 & 5.00 \\
\hline
\end{tabular}

The thresholds for surface water to produce drinking water (Italian Law 152/1999) were used for pH ad orthophosphate. Key: SE, standard error; *, value over the limit only once (in May or July or September 2020); **, value over the limit for more than one sampling period

\section{Discussion}

Vegetation and water

The floristic-vegetational results of the four spring-wells show signs of environmental degradation but also valuable elements that are common to all four study areas at various level. The high number and/or coverage of ruderal therophytes of Stellarietea mediae class living in the spring-wells banks/ 
Fig. 6 CCA ordination biplots of spring-wells (A, $\mathbf{B}, \mathbf{C}$ and $\mathbf{D})$ associated with water features and species identified in the spring-wells beds. Key: Temp., water temperature; Kubel, organic substance; $\mathrm{pH}$, water $\mathrm{pH} ; \mathrm{NO}_{2}{ }^{-}$, nitrite; $\mathrm{NO}_{3}{ }^{-}$, nitrate; $\mathrm{NH}_{4}{ }^{+}$, ammonium; $\mathrm{Cl}^{-}$, chloride; $\mathrm{PO}_{4}{ }^{3-}$, orthophosphate; Equisetum_t, Equisetum telmateia; Helosciadium_n, Helosciadium nodiflorum; Callitriche_o, Callitriche obtusangula; Glechoma_e, Glechoma hederacea; Solanum_n, Solanum nigrum; Agrostis_s, Agrostis stolonifera; Veronica_a, Veronica anagallis-aquatica; Poa_p, Poa palustris; Lythrum_s, Lythrum salicaria; Phalaroides_a, Phalaroides arundinacea; Lemna_m, Lemna minor; Hypericum_t, Hypericum tetrapterum; Algae, algae

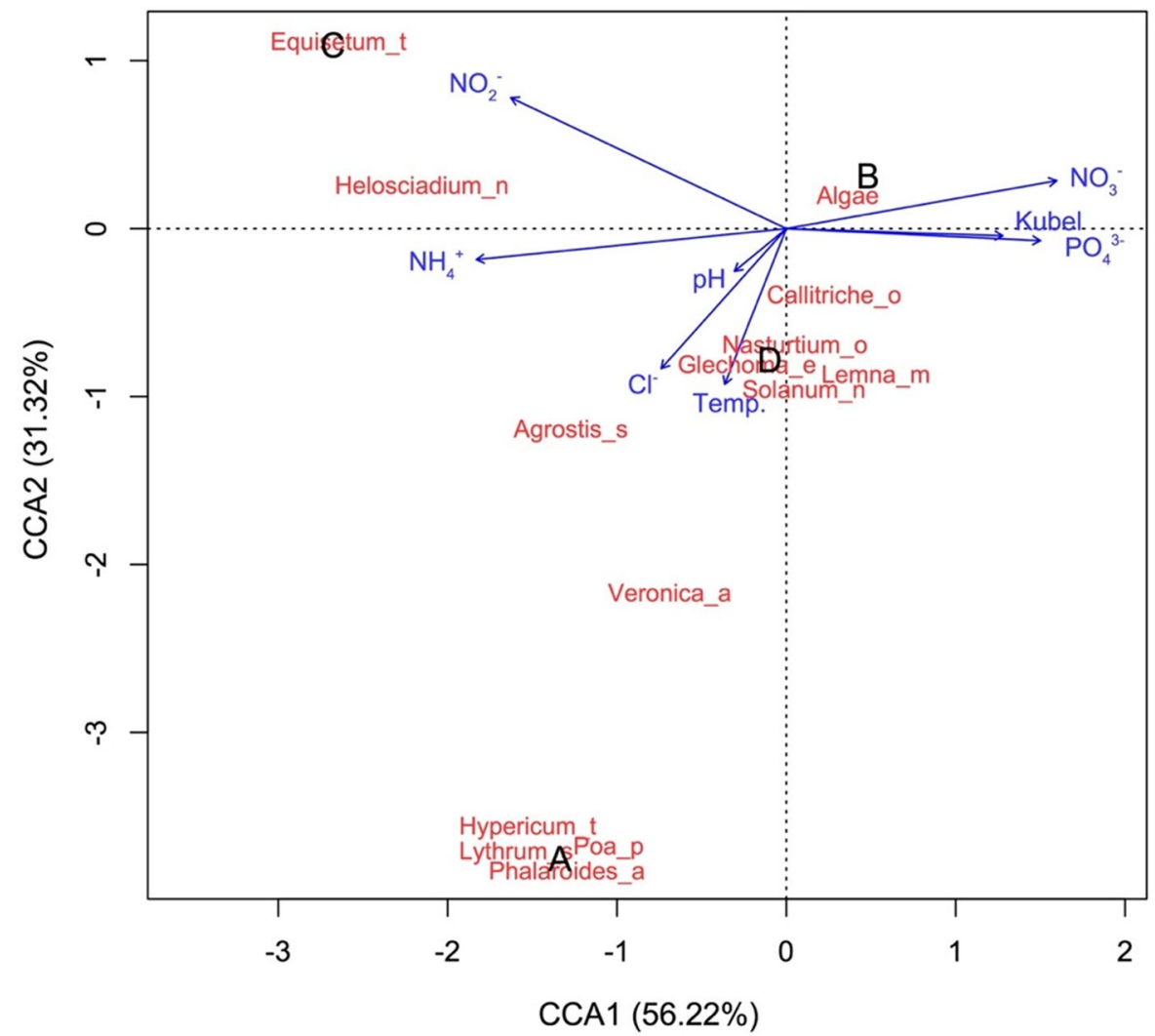

edges, and even more in the corn fields, is a clear sign of disturbance as suggested by the low EIM value (far lower than the maximum value of 9 related to a mature wood free from exotic species) (Fig. 5). Such disturbance is caused by human activities, more precisely it is due to the intensive management of the surrounding fields and to the presence of urban areas around the considered spring-wells. These wetlands are deeply influenced by the adjacent highly disturbed areas as corn fields where IM and EIM values are extremely low (Fig. 5). Similar values were found for other corn fields of Po Plain (Giupponi et al. 2013) and are due to the presence of annual/short lived species (mainly cosmopolitan or exotic species) of the initial stages of the plant succession. These species can reach the banks because spring-wells are patchy and narrow (not extended in width) in the agricultural and urban landscape that characterizes a great part of Po Plain (Bischetti et al. 2012). The low EIM value of banks vegetation is also determined by the presence of the most diffused trees naturalized in Po Plain, especially on the edges of fields and roads and in little wooded spots as Robinia pseudoacacia and Ailanthus altissima (Del Favero 2002; Celesti-Grapow et al. 2009). White mulberry (Morus alba) can be added to these. Even though being an exotic plant, it can be considered an added value if present in these environments. White mulberry is in fact a Moraceae native to Eastern Asia probably introduced in Europe in the XII century (archeophyte) for silkworm farming (Bombyx mori) and grown in Italy from the XV Century (Bof 2017). At the end of the Nineteenth century Italy was the main producer of silk in Europe (Bof 2017), in Brescia, for example, during 1825, 26.800 tons of cocoons were produced (Fappani and Maffeis 1994; Bof 2017). Then, from the beginning of the Twentieth century, when synthetic textile fibres were introduced and importing silk from China became cheaper, the silkworms breeding in Italy and consequently the cultivation of the white mulberry narrowed gradually and almost totally disappeared in many Italian areas (Bof 2017). The presence of mulberry in all the spring-wells under study is therefore an element of historical and cultural value as a memory of agricultural activities, landscapes and agro-ecosystems of Po Plain almost totally disappeared today. IM and EIM, 
as formulated by their authors (Taffetani and Rismondo 2009; Rismondo et al. 2011; Giupponi et al. 2015), do not consider the historical-cultural value that some exotic species (as white mulberry) can have if present in determined environments (agro-ecosystems). The limit of these indexes is to consider every exotic species as a degradation and disturbance element, aspect that could be overcome integrating these indexes or creating new ones able to consider the historical-cultural value of these kind of exotic species in the plant communities where they are present.

Beyond the ruderal spontaneous species and the exotic invasive/naturalized species that naturally colonized the banks of the spring-wells, ornamental (exotic) species planted out of controls by local inhabitants (oral communication) were detected. These species, although not invasive, contribute to the degradation of the spring-wells either from an ecological (they lower EIM values) and physiognomic/landscaping point of view and their presence suggests the necessity of involving the local community in outreach/formative activities (Schild 2016). This would empower people awareness on the value and biological, scenic, and cultural importance of spring-wells and to know the basic concepts of nature conservation.

Operational and legislative initiatives to counteract the spread of exotic plants have multiplied in the last decades, from the local to the international scale (Brundu et al. 2020), because they can cause imbalances to ecosystems and damages that can even impact in the socio-economic field or human health (Celesti-Grapow et al. 2009; Vilà et al. 2011). Many of the exotic ornamental species in the spring-wells under observation are not invasive but some seem naturalized species (i.e., Oxalis articulata, Fig. 3e). It would therefore be appropriate to start their removal or at least to monitor their spreading, since all the naturalised species represent potential invasive species (Richardson and Pyšek 2012). Operational actions to remove and/or monitor the spreading of exotic species can be framed in three principal typologies: mechanical, chemical, and biological control. The mechanical control (such as extirpation or repeated cuts of vegetation) achieves the best results (van Wilgen et al. 2000) and in many cases is the only possible solution ecologically sustainable. The use of polluting chemicals is in fact to avoid in natural or semi-natural environments for their possible impact on native species and other ecosystems' components (soil, water, etc.) (FOEN 2006). Biological control intended as the competition effect played by other vegetal species or the use of other living organisms (i.e., bacteria, fungi, insects etc.) able to reduce the vigour of exotic species (Sitzia et al. 2016), could be an interesting and low impact strategy, also for wetlands. The results of a research conducted by Rayamajhi et al. (2009) highlighted how some wetland forests of south Florida dominated by an exotic tree (Melaleuca quinquenervia) were partially restored after about a decade thanks to the use of its natural-enemys. This kind of research should be encouraged in the future to understand which are and where it is possible to use the natural enemies of the main invasive species to limit their diffusion without affecting native species and other ecosystems' components.

Together with the ruderal and exotic species, the floristic analysis allowed the identification of native species typical of Po Plain wetlands, as the ones of Lemnetea minoris, Potametea pectinatii, Phragmito australis-Magnocaricetea elatae and Salici purpureae-Populetea nigrae phytosociological classes (Table S2). These species present in areas I and II, represent the biological-naturalistic valuable element of the spring-well analysed. This applies particularly for spring-well A that is the richest in wetland species some of which found exclusively (such as: Carex riparia and Lythrum salicaria) and/or that have noteworthy coverage (such as: Poa palustris, Phalaroides arundinacea and Populus nigra) on the banks/edges of this specific spring-well. Spring-well A could be then employed as "source" area where to collect plant material (seeds or other propagation organs) to employ in possible re-introduction/re-population or ecological restoration initiatives of this or nearby spring-wells banks/edges ("sink" areas).

The riverbed of the spring-wells (zone I), although it has much less species comparing to banks/edges, does not present exotic species, and in fact its EIM and IM values are higher comparing to the ones of banks/edges vegetation (Fig. 5). Such value is however far from the maximum EIM value (9) for the reason that in zone I, a series of biotic and abiotic disturbances more or less recent (among which the constant presence of running water and the excavation and cleaning initiatives of the riverbed and spring-wells) hamper the establishment of a soil layer able to host species of the mature forest typical of Po Plain. In 
zone I, additionally to the absence of exotic species, there are some species uncommon/rare in Lombardy and in general in Italy as Callitriche obtusangula. From the analysis of the chemical-phyisical features of spring-wells (Table 2) and from CCA (Fig. 6) it might seem that Callitriche obtusangula needs eutrophic waters with a high nitrate, phosphates, and organic substance concentration as in spring-well B in which Callitriche obtusangula has interesting values of coverage and algae are abundant (Table S2; Fig. 1). Conversely, in waters poorer in phosphates, nitrate and organic substance, Callitriche obtusanguala is less abundant (as well as algae) till being totally absent in spring-well $\mathrm{C}$, that is the one with the least eutrophic water and that presents the minor number of species (3) in the riverbed (Table S2). The presence of Callitriche obtusangula in polluted waters is explained by being a nitrophilous and salt dependent species ("ss", Landolt et al. 2010), according to Landolt et al. (2010) and Ellenberg and Leuschner (2010). Hence its presence, associated to algal uncontrolled growth, it is to consider an indicator of slow running waters particularly rich in nutrients/pollutants (eutrophic waters). Equisetum telmateia abundance in the riverbed and riverbanks of spring-well $\mathrm{C}$ could be instead due to minor nutrient requirements comparing to Callitriche obtusangula and to the fact that this species is not salt tolerant (Ellenberg and Leuschner (2010); Landolt et al. 2010). This only partially explains the results of the research, since spring-well $\mathrm{C}$ waters have low nitrate, orthophosphate and organic substance content, but a high content in nitrite $(0.29 \mathrm{ppm})$. So, tailor made studies would be necessary to understand if the presence of nitrite in the water (and/or in the soil) can be or not a factor able to favour Equisetum telmateia or if this species is instead favoured by the low concentration of nitrate, phosphate and organic substance.

Water $\mathrm{pH}$ values of the considered spring-wells are very similar and coherent with the values of other spring-wells in Po Plain measured by Cavagnis and Orsini (1992) and Balestrini et al. (2021) while temperature measured where the water springs resulted slightly higher $\left(16.16 \pm 0.41^{\circ} \mathrm{C}\right)$ comparing other values in previous research (Cavagnis and Orsini 1992). The chloride content, even if far below the threshold (250 ppm), resulted slightly higher (Table 2) comparing with values reported in other studies (De Luca 2014; Balestrini et al. 2021). To regularly monitor the chemical-physical water parameters of springwells would be advisable, as well as of the aquifers in densely populated and industrialized areas (De Caro et al. 2017) to highlight possible critical circumstances where to act for the conservation/restoration of these environments. Monitoring data of water and other ecological parameters could be useful to develop innovative instruments (or implement already existing ones) to help territorial managers to decide which wetlands need primarily an intervention of restoration, as realized by Almendinger (1998) and Fumagalli et al. (2017). These instruments would be even more effective if supported by data collected in the field. A multidisciplinary approach for wetlands characterization would be opportune also if difficult to realize for the elevated number of wetlands and of the parameters to consider. Chemical-physical and ecological parameters could be however reduced identifying good environmental indicators, one of which could be the vegetation itself, as suggested by other authors (Clayton and Edwards 2006; Serteser et al. 2008; Giupponi et al. 2013; Alemu et al. 2017).

Management practices for the ecological conservation

Considering this research results, some management proposals to increase the ecological and cultural-historical value of the analysed spring-wells or others in similar conditions are provided below.

The relevant presence of exotic/ruderal species inhabiting land to the disadvantage of native and typical species of Po Plain wetlands is one of the main problems to solve. Figure 7 shows an operational scheme to remove ornamental/exotic trees and shrubs replacing them with native woody species typical of hygrophilous woods of Po Plain. Removing ornamental/exotic shrubs and trees (excepting the oldest Morus alba with an historical-cultural value) must be carried out gradually over time (van Wilgen et al. 2000), starting from shrubs (Fig. 7). Removing the highest ornamental/exotic trees or the ones with the most developed foliage could in fact create clearings favourable to the development of new exotic naturalized plants as Robinia pseudoacacia and Ailanthus altissima that are heliophilous invasive species (Landolt et al. 2010) found in the spring-wells and in general in a great part of Po Plain (Del Favero 2002; Pignatti 2017; Fogliata et al. 2021). Thus, removing exotic/ornamental shrubs and trees, leaving the 


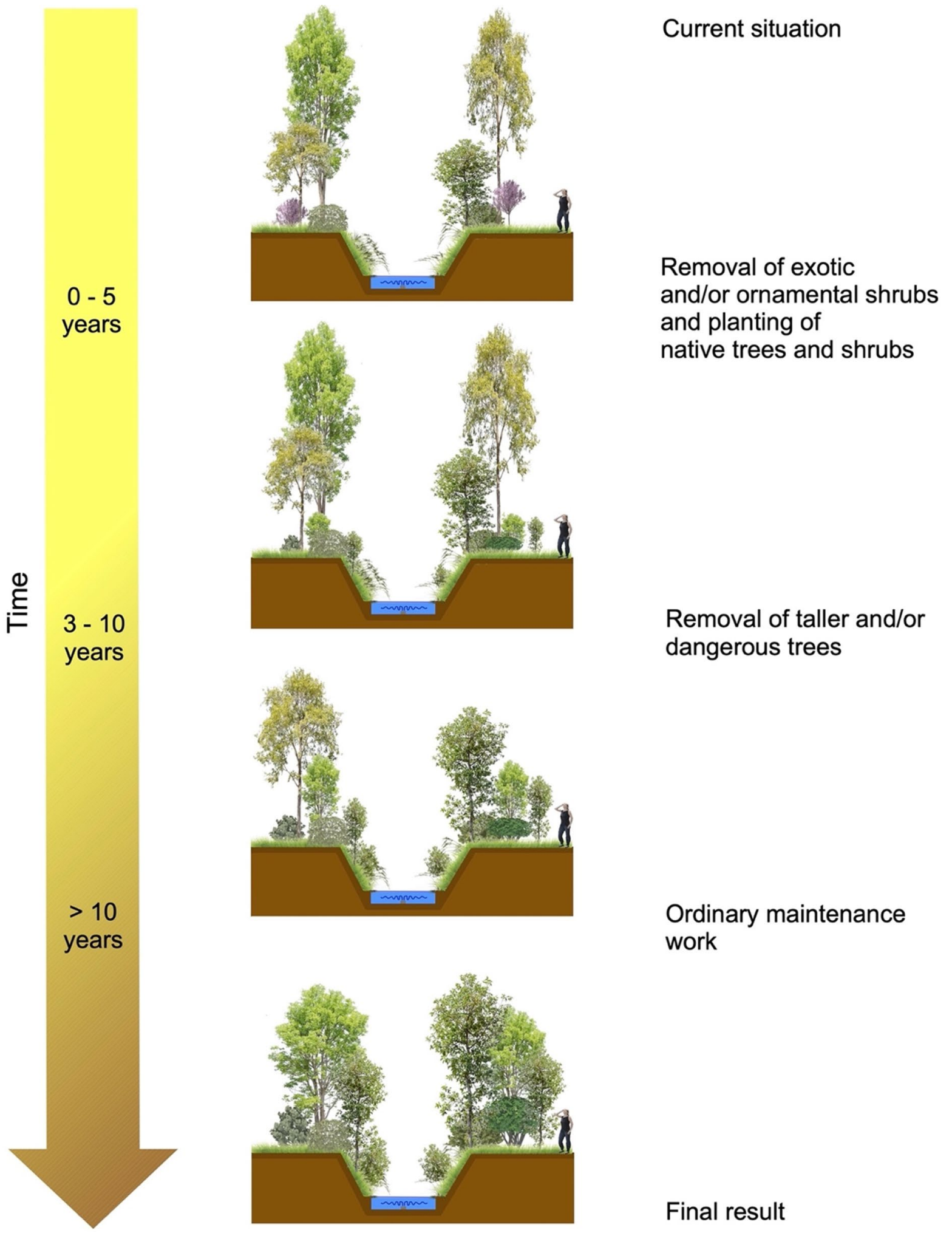

Fig. 7 Scheme of the work to carry out over ten years to improve the ecological characteristics of the vegetation (trees and shrubs) of the spring-wells banks/edges 
highest trees, would reduce exotic invasive species growth and allow the implantation of native plants less heliophilous as Cornus sanguinea, Acer campestre, Sambucus nigra, Corylus avellana, Alnus glutinosa, Salix alba, Populus nigra and Carpinus betulus. These essences should be planted before the vegetative restart (fall, and/or late winter) considering their needs concerning the soil humidity. In fact, some cited trees/shrubs (Alnus incana, Salix alba and Populus nigra) are particular of alluvial forests and need a waterlogged soil (always or periodically) while others are in optimal growth conditions in soils not soaked with water. For this reason, planting the most hygrophilous species in the lower part or spring-wells riverbank (little over the water level) and the others in the higher part (1-2 m over the water level) would be advisable. Besides the cited species (present at least in one of the analysed spring-wells), planting the common oak (Quercus robur) would be worthwhile. This oak species is in fact increasingly rare in Po Plain even if it is, together with hornbeam (Carpinus betulus), one of the tree species representing the "current potential vegetation" (Biondi 2011) of Po Plain (Del Favero 2002; Verde et al. 2010). Once the young native trees/shrubs have taken seeds and after they created a dense shrubland, it will be possible to eliminate the highest exotic trees and the ones dangerous for people and goods (Fig. 7). Passing the years, the young native trees and shrubs will go on growing and expanding, thus improving the floristic and ecological features of the spring-wells vegetation. At this stage the management operations of trees/shrubs would be limited to the removal of dead/unstable plants (Fig. 7) and to the vegetation destruction after landslides on the riverbanks (often very steep, Table S2) in extraordinary circumstances. The intervention with low-impact soil stabilization works as soil bioengineering based on plants (or parts thereof) as building materials in combination with dead materials (such as stones, steel, iron, timber, etc.) would be advisable (Bischetti et al. 2014).

While the control of exotic/ornamental trees/shrubs on the riverbanks represents an operation relatively easy, the removal of ruderal and exotic herbaceous species could be much more difficult and expensive (van Wilgen et al. 2000). A great part of the exotic weeds found in the spring-wells are heliophilous species (as for example: Phytolacca americana, Erigeron canadensis and Ambrosia artemisiifolia) recurrent in Po Plain (Celesti-Grapow 2009; Pignatti 2017). Therefore, once built a dense shrubland (see above) and limiting the quantity of light in the herbaceous layer of the vegetation, the most heliophilous exotic and annual ruderals (therophytes) should reduce and the least heliophilous could be removed by qualified technicians (van Wilgen et al. 2000). Sowing or planting young plants of herbaceous species could be planned to encourage the establishment of wetlands. In this case a more structured environmental restoration project involving specialized centres/university could be envisioned. Sowing the native wetlands species of Po Plain could be then an option. However, finding this material in Italy is regrettably difficult (if not impossible), as Italy, comparing to other European countries, has very few producers of native seeds. It is sufficient to consider that in Italy there are only three producers ("Seme Nostrum", "Centro Flora Autoctona" and "Flora Conservation") (Giupponi and Leoni 2020) while in Germany there are 12 (Prasse et al. 2010) as well as they are more numerous in Switzerland (SKEW 2009). The shortage of native seeds producers in Italy is due principally to the lack of regulatory instruments to govern the use of autochthonous seeds in restoration work (De Vitis et al. 2017), issue to sort out as soon as possible to favour and improve the restoration of wetlands vegetation (Giupponi et al. 2017b, 2019).

For what concerns the riverbeds of the springwells (zone I), given the absence of exotic species, possible interventions of re-introduction/re-colonization are the only actions to consider. In this zone, changes of the physical-chemical characteristics of the water and removing/upset the mud layer of the riverbed where hydrophytes as Callitriche obtusangula can root are to avoid. While the mechanic disturbance of the spring-well riverbeds is an action relatively easy to control as it is mainly attributable to human cleaning intervention, controlling the chemical-physical water and mud features is more difficult as they depend on both climatic and land use factors (Kløve et al. 2014; Balestrini et al. 2021). In the case study the high nitrogen content (in particular ammonium and nitrite), phosphates and organic substance is reasonably ascribable to the use of frequently employed intensive agriculture products (as ammonium nitrate) or possible industrial/urban discharges. Considering the difficulties of depurating groundwaters (Balestrini et al. 2008, 2018), this 
issue could be at least reduced identifying and stopping possible uncontrolled spills of discharge water in the spring-wells or nearby areas, and/or limiting the use of polluting chemicals in the fields adjacent the study areas. This last action could be facilitated by instituting one or more protected areas (as local park of supra-municipal interest - PLIS) able to protect spring-wells creating also buffer areas where only low-input agricultural techniques (as organic agriculture) can be employed. If land managers want to start the depuration and/or protect spring-well groundwaters against pollution in accordance with the European directive (EC 2006), the trade-off showed in this research will be to take into consideration: polluted/ eutrophic waters favour the growth (and conservation) of Callitriche obtusangula while oligotrophic waters limit this rare species. In this case, a situation of compromise would seem ideal, meaning waters moderately eutrophic (with nutrients/pollutants values possibly under the legal threshold) that however allow the growth of Callitriche obtusangula. Finally, for what concerns the water temperature at the spring, the higher values comparing to other research works (Cavagnis and Orsini 1992), could be due to global warming (Kløve et al. 2014), aspect that is extremely difficult to manage in particular at a local scale.

\section{Conclusion}

This study characterizes the vegetation of some spring-wells in one of the most industrialized and inhabited areas of Europe, Po Plain. The four studied spring-wells shows similar ecological and floristicvegetational features, some of which are clear indication of environmental disturbance/degradation while others add value to these environments. The high presence of exotic and/or annual ruderal species as well as eutrophic waters notably containing ammonium (even over the legal limit) and, in some cases, orthophosphate and organic substance are among the disturbance indicators. However, spring-wells shows better floristic and ecological features comparing to the corn fields dominating Po Plain and includes species of historical-cultural value as Morus alba and rare, in Lombardy and in general in Italy, as Callitriche obtusangula, an hydrophyte requiring slow eutrophic waters. The results also allowed the formulation of management proposals useful for land managers to enhance the environmental, historicalcultural, and scenic value of the studied spring-wells and other with similar characteristics in Po Plain, deserving valorisation and protection.

Acknowledgements We wish to thank Linda Molinelli for her work in in the laboratory and Marco Bessi of Oglio Mella Reclamation Consortium for his support. This research was supported by "AcquaPluSS" project and by "Montagne: Living Labs di innovazione per la transizione ecologica e digitale" project.

Author contributions Conceptualization: LG, GBB; Methodology: LG, GB; Formal analysis and investigation: LG, GB, VL, MZ; Writing - original draft preparation: LG, VL, GB; Writing-review and editing: LG, VL; Funding acquisition: GBB; Supervision: LG, GBB.

Funding This research was supported by "AcquaPluSS" project and by "Montagne: Living Labs di innovazione per la transizione ecologica e digitale" project.

Data availability Not applicable.

Code availability Not applicable.

\section{Declarations}

Conflict of interest Authors declare that they have no conflicts of interest.

Open Access This article is licensed under a Creative Commons Attribution 4.0 International License, which permits use, sharing, adaptation, distribution and reproduction in any medium or format, as long as you give appropriate credit to the original author(s) and the source, provide a link to the Creative Commons licence, and indicate if changes were made. The images or other third party material in this article are included in the article's Creative Commons licence, unless indicated otherwise in a credit line to the material. If material is not included in the article's Creative Commons licence and your intended use is not permitted by statutory regulation or exceeds the permitted use, you will need to obtain permission directly from the copyright holder. To view a copy of this licence, visit http://creativecommons.org/licenses/by/4.0/.

\section{References}

Albergoni F, Spreafico E, Toso S (1977) Profilo ecologico dei fontanili del Cremasco. Giorn Bot Ital 111:71-83

Alemu T, Weyuma T, Alemayehu E, Ambelu A (2017) Identifying riparian vegetation as indicator of stream water quality in the Gilgel Gibe catchment, southwestern Ethiopia. Ecohydrology 11:e1915. https://doi.org/10.1002/eco. 1915 
Alessandrini A, Bonaposta D, Pezzoli S (2011) Sorgenti libere e fontanili storicamente documentati: un contributo alla tutela e valorizzazione. In: Panizza M, Paganoni A, Pignone R, Testa B, Valletta M (eds) Geologia e TurismoAtti del Quarto convegno Nazionale. Centro Stampa della Giunta Regionale della Regione Emilia-Romagna, Bologna, pp 51-53

Almendinger J (1998) A method to prioritize and monitor wetland restoration for water-quality improvement. Wetl Ecol Manag 6:241-252. https://doi.org/10.1023/A:1008439031 165

Andreis C (2002) I distretti geobotanici. In: Del Favero R (ed) I tipi forestali della Lombardia. Cierre, Verona, pp 36-40

Balestrini R, Arese C, Delconte C (2008) Lacustrine wetland in an agricultural catchment: nitrogen removal and related biogeochemical processes. Hydrol Earth Syst Sci 12:539550. https://doi.org/10.5194/hess-12-539-2008

Balestrini R, Sacchi E, Tidili D, Delconte CA, Buffagni A (2016) Factors affecting agricultural nitrogen removal in riparian strips: examples from groundwater dependent ecosystems of the Po Plain (northern Italy). Agric Ecosyst Environ 221:132-144. https://doi.org/10.1016/j.agee. 2016.01.034

Balestrini R, Delconte C, Palumbo MT, Buffagni A (2018) Biotic control of in-stream nutrient retention in nitrogenrich springs (PoValley, northern Italy). Ecol Eng 122:303314. https://doi.org/10.1016/j.ecoleng.2018.08.014

Balestrini R, Delconte C, Sacchi E, Buffagni A (2021) Groundwater-dependent ecosystems as transfer vectors of nitrogen from the aquifer to surface waters in agricultural basins: the fontanili of the Po Plain (Italy). Sci Total Environ 753:141995. https://doi.org/10.1016/j.scitotenv.2020. 141995

Bertolani Marchetti D (1959) La vegetazione dei fontanazzi modenesi. Webbia 15:141-167

Bertuletti C (1992) Note idrogeologiche sulle risorgive lombarde. Riv Mus Civ Sc Nat "E. Caffi" Bergamo 15:409-420

Biondi E (2011) Phytosociology today: methodological and conceptual evolution. Plant Biosyst 145(suppl 1):19-29. https://doi.org/10.1080/11263504.2011.602748

Biondi E, Blasi C, Allegrezza M, Anzellotti I, Azzella MM, Carli E et al (2014) Plant communities of Italy: the vegetation prodrome. Plant Biosyst 148:728-814. https://doi. org/10.1080/11263504.2014.948527

Biondi E, Blasi C (2015) Prodromo della vegetazione d'Italia. http:// www.prodromo-vegetazione-italia.org. Accessed 1 May 2021

Bischetti GB, Di Fidio M, Florineth F (2014) On the origin of soil bioengineering. Landsc Res 39:583-595. https://doi. org/10.1080/01426397.2012.730139

Bischetti G, Fumagalli N, Gomarasca S, Pillitter T, Piantanida E, Senes G, Negri G, Marziali L, Toccolini A (2012) Tutela e valorizzazione dei fontanili del territorio lombardo. Quaderni della Ricerca n. 144. D.G. Agricoltura, Regione Lombardia

Blasi C, Capotorti G, Copiz R, Guida D, Mollo B, Smiraglia D, Zavattero L (2014) Classification and mapping of the ecoregions of Italy. Plant Biosyst 148:1255-1345. https:// doi.org/10.1080/11263504.2014.985756
Bof F (2017) Sericoltura e setificio in Italia tra Otto e Novecento: una rassegna bibliografica. In: De Matteo L (ed) Storia Economica Anno XX (2017) - n.2. Edizioni Scientifiche Italiane, Napoli, pp 649-672

Braun-Blanquet J (1964) Pflanzensoziologie, 3rd edn. Springer, Wien

Brundu G, Armeli Minicante S, Barni E et al (2020) Managing plant invasions using legislation tools: an analysis of the national and regional regulations for non-native plants in Italy. Ann Bot 10:1-12. https://doi.org/10.13133/22393129/16508

Canullo R, Allegrini M-C, Campetella G (2012) Reference field manual for vegetation surveys on the CONECOFOR LII network, Italy (National Programme of Forest Ecosystems Control - UNECE, ICP Forests). Braun-Blanquetia 48:5-65

Cavagnis E, Orsini G (1992) Considerazioni sulle analisi chimiche e chimico-fisiche delle acque di alcuni fontanili lombardi. Riv Mus Civ Sc Nat "E Caff" Bergamo15: 421-426

Celesti-Grapow L, Alessandrini A, Arrigonic PV et al (2009) Inventory of the non-native flora of Italy. Plant Biosyst 143:386-430. https://doi.org/10.1080/1126350090 2722824

Clayton J, Edwards T (2006) Aquatic plants as environmental indicators of ecological condition in New Zealand lakes. Hydrobiologia 570:147-151. https://doi.org/10.1007/ s10750-006-0174-4

CNR-IRSA (Consiglio Nazionale delle Ricerche - Istituto di Ricerca sulle Acque) (2003) Metodi analitici per le acque, Manuali e Linee Guida 29/2003. APAT, Agenzia per la protezione dell'ambiente e per i servizi tecnici.

Corbetta F (1969) La vegetazione dei fontanili lomellini. Giorn Bot Ital 103:19-32

D'Auria G, Zavagno F (2005) I fontanili della provincia di Cremona - Censimento 1998-2004. Monografie di Pianura 6. Provincia di Cremona, Cremona

Davidson NC (2014) How much wetland has the world lost? Long-term and recent trends in global wetland area. Mar Freshw Res 65:936-941. https://doi.org/10.1071/MF141 73

De Caro M, Crosta GB, Frattini P (2017) Hydrogeochemical characterization and natural background levels in urbanized areas: Milan Metropolitan area (Northern Italy). J Hydrol 547:455-473. https://doi.org/10.1016/j.jhydrol. 2017.02.025

De Luca DA, Ghione R, Lasagna M (2005) Studio idrogeologico dei Fontanili della Pianura Piemontese. Giornale Di Geologia Applicata 2:377-382

De Luca DA, Destefanis E, Forno MG, Lasagna M, Masciocco L (2014) The genesis and the hydrogeological features of the Turin Po Plain fontanili, typical lowland springs in northern Italy. Bull Eng Geol Environ 73:409-427. https://doi.org/10.1007/s10064-013-0527-y

De Vitis M, Abbandonato H, Dixon KW, Laverack G, Bonomi C, Pedrini S (2017) The European Native Seed Industry: Characterisation and Perspectives in Grassland Restoration. Sustainability 9:1682. https://doi.org/10. 3390/su9101682

Del Favero R (2002) I tipi forestali della Lombardia. Cierre, Verona 
EC (1992) Council Directive 92/43/EEC of 21 May 1992 on the conservation of natural habitats and of wild fauna and flora. Official Journal L 206, 0007-0050 22/07/1992

EC (2006) Directive 2006/118/EC of the European Parliament and of the Council of 12 December 2006 on the protection of groundwater against pollution and deterioration. Offic J Eur Union L 372:19-28

EC (2015) Technical Report on Groundwater Associated Aquatic Ecosystems (2015). Technical Report - 2015093. ISBN 978-92-79-53895-7. https://doi.org/10.2779/ 6042. Accessed 1 May 2021

Ellenberg H, Leuschner C (2010) Vegetation Mitteleuropas mit den Alpen. Verlag Eugen Ulmer, Stuttgart

Fappani A, Maffeis F (1994). Gelso baco e seta nel Bresciano. Brescia

FOEN (2006) Invasive alien species in Switzerland. Environ Stud 157

Fogliata P, Cislaghi A, Sala P, Giupponi L (2021) An ecological analysis of the riparian vegetation for improving the riverine ecosystem management: the case of Lombardy region (North Italy). Landsc Ecol Eng 17:375-386. https://doi.org/10.1007/s11355-021-00451-0

Frattini S (2008) Zone umide della pianura bresciana e degli anfiteatri morenici dei laghi d'Iseo e di Garda. Monografie di Natura Bresciana 29

Fumagalli N, Senes G, Ferrario PS, Toccolini A (2017) A minimum indicator set for assessing fontanili (lowland springs) of the Lombardy Region in Italy. Eur Countrys 9:1-16. https://doi.org/10.1515/euco-2017-0001

Giupponi L, Leoni V (2020) Alpine pioneer plants in soil bioengineering for slope stabilization and restoration: results of a preliminary analysis of seed germination and future perspectives. Sustainability 12:7190. https://doi.org/10. 3390/su12177190

Giupponi L, Corti C, Manfredi P, Cassinari C (2013) Application of the floristic-vegetational indexes system for the evaluation of the environmental quality of a semi-natural area of the Po Valley (Piacenza, Italy). Plant Sociol 50:47-56

Giupponi L, Bischetti GB, Giorgi A (2015) Ecological index of maturity to evaluate the vegetation disturbance of areas affected by restoration work: a practical example of its application in an area of the Southern Alps. Restor Ecol 23:635-644. https://doi.org/10.1111/rec.12232

Giupponi L, Bischetti GB, Giorgi A (2017a) A proposal for assessing the success of soil bioengineering work by analysing vegetation: results of two case studies in the Italian Alps. Landsc Ecol Eng 13:305-318. https://doi.org/10. 1007/s11355-016-0323-5

Giupponi L, Bischetti GB, Giorgi A (2017b) Vegetation analysis and estimation of forest reconstitution time in protected areas of Val Camonica (Southern Alps) where a commercial mixture of seeds was sown. Ecomont 9:22-29. https:// doi.org/10.1553/eco.mont-9-1s22

Giupponi L, Borgonovo G, Giorgi A, Bischetti GB (2019) How to renew soil bioengineering for slope stabilization: some proposals. Landsc Ecol Eng 15:37-50. https://doi.org/10. 1007/s11355-018-0359-9

He J, Moffette F, Fournier R et al (2015) Meta-analysis for the transfer of economic benefits of ecosystem services provided by wetlands within two watersheds in Quebec,
Canada. Wetlands Ecol Manage 23:707-725. https://doi. org/10.1007/s11273-015-9414-6

Heukelekian H, Bloodgood DE, Edwards GP, Ettinger MB, Hoak RD, Ingols RS et al (1954) Analytical methods. Sewage Indust Wastes 26:573-582

Hu S, Niu Z, Chen Y, Li L, Zhang H (2017) Global wetlands: Potential distribution, wetland loss, and status. Sci Total Environ 586:319-327. https://doi.org/10.1016/j.scitotenv. 2017.02.001

Kløve B, Ala-aho P, Bertrand G, Boukalova Z, Ertürk A, Goldscheider N, Ilmonen J, Karakaya N, Kupfersberger H, Kvoerner J, Lundberg A, Mileusnic M, Moszczynska A, Muotka T, Preda E, Rossi P, Siergieiev D, Šimek J, Wachniew P, Angheluta V, Widerlund A (2011) Groundwaterdependent ecosystems. Part I: hydroecological status and trends. Environ Sci Pol 14:770-781. https://doi.org/10. 1016/j.envsci.2011.04.002

Kløve B, Ala-Aho P, Bertrand G, Gurdak JJ, Kupfersberger H, Kværner J, Muotka T, Mykrä H, Preda E, Rossi P, Bertacchi Uvo C, Velasco E, Pulido-Velazquez M (2014) Climate change impacts on groundwater and dependent ecosystems. J Hydrol 518:250-266. https://doi.org/10.1016/j. jhydrol.2013.06.037

Kruse JM, Mellon MG (1953) Colorimetric determination of ammonia and cyanate. Anal Chem 25:1188-1192

Landolt E, Bäumler B, Erhardt A, Hegg O, Klötzli F, Lämmle RW et al (2010) Flora indicativa. Ecological indicator values and bio- logical attributes of the Flora of Switzerland and the Alps. Haupt Verlag, Bern

Legendre P, Gallagher ED (2001) Ecologically meaningful transformations for ordination of species data. Oecologia 129:271-280. https://doi.org/10.1007/s004420100716

Lin Q, Yu S (2018) Losses of natural coastal wetlands by land conversion and ecological degradation in the urbanizing Chinese coast. Sci Rep 8:15046. https://doi.org/10.1038/ s41598-018-33406-x

Martini F, Bona E, Federici G, Fenaroli F, Perico G et al (2012) Flora vascolare della Lombardia centro-orientale. Lint, Trieste

Martinis B, Pozzi R, Cavallin A, Mancuso M (1976) Indagine sugli acquiferi della Lombardia centro-settentrionale. Quaderni IRSA-indagine sulle falde acquifere profonde della Pianura Padana. CNR-IRSA, Roma

MEA (2005) Ecosystems and human well-being: synthesis. Island Press, Washington DC

Menzel DW, Corwin N (1965) The measurement of total phosphorus in seawater based on the liberation of organically bound fractions by persulfate oxidation. Limnol Oceanogr 10:280-282

Minelli A, Ruffo S, Stoch F, Cosentino A, La Posta A, Morandini C, Muscio G, Lapini L, Paradisi S, Sburlino G, Solari M (2002) Risorgive e fontanili. In: Acque sorgenti di pianura dell'Italia Settentrionale, Ministero dell'Ambiente, Museo Friulano di Storia Naturale, Comune di Udine, pp 13-28

Mitra S, Wassmann R, Vlek P (2003) Global inventory of wetlands and their role in the carbon cycle. Discus Pap 18771

Mucina L, Grabherr G, Ellmauer T, Wallnöfer S (1993) Die Pfanzengesellschaften Österreichs. Gustav Fischer Verlag, Jena 
Oksanen J, Blanchet FG, Friendly M, Kindt R, Legendre P, McGlinn D, Minchin PR, O'Hara RB, Simpson GL, Solymos P, Stevens MHH, Szoecs E, Wagner H (2019). Vegan: Community Ecology Package. R package version 2.5-6

Piazzoli Perroni A (1959) Ricerche sulla flora e la vegetazione dei fontanili dell'agro milanese. Nuovo Giorn Bot Ital 63:355-410

Pignatti S (2017) Flora d'Italia. Edagricole, Bologna

Pisoni R, Valle M (1992) Valutazione biologica di alcuni fontanili della Lombardia. Riv Mus Civ Sc Nat "E. Caffi" Bergamo 15:427-452

Prasse R, Kunzmann D, Schröder R (2010) Entwicklung und Praktische Umsetzung Naturschutzfachlicher Mindestanforderungen an Einen Herkunftsnachweis fuör Gebietseigenes Wildpflanzensaatgut Krautiger Pflanzen. Institute for Environmental Planning of the Gottfried Wilhelm Leibniz Universitaöt, Hannover

R Development Core Team (2021) R: a language and environment or statistical computing. R Foundation for Statistical Computing, Vienna

Ramsar Convention Bureau (2001) Wetlands values and functions. Ramsar Convention Bureau, Gland

Raunkiaer C (1934) The life form of plants and statistical plant geography. The Clarendon Press, Oxford

Rayamajhi MB, Pratt PD, Center TD et al (2009) Decline in exotic tree density facilitates increased plant diversity: the experience from Melaleuca quinquenervia invaded wetlands. Wetl Ecol Manage 17:455-467. https://doi.org/10. 1007/s11273-008-9123-5

Richardson DM, Pyšek P (2012) Naturalization of introduced plants: ecological drivers of biogeographical patterns. New Phytol 196:383-393. https://doi.org/10.1111/j.14698137.2012.04292.x

Rismondo M, Lancioni A, Taffetani F (2011) Integrated tools and methods for the analysis of agroecosystem's functionality through vegetational investigations. Fitosociologia 48:41-52

Rivas-Martínez S, Penas A, Díaz TE (2004) Biogeographic map of Europe. http://www.globalbioclimatics.org/form/ maps.htm. Accessed 1 May 2021

Schild R (2016) Environmental citizenship: what can political theory contribute to environmental education practice? J Environ Educ 47:19-34. https://doi.org/10.1080/00958 964.2015.1092417

Serteser A, Kargığlu M, Içağa Y et al (2008) Vegetation as an Indicator of Soil Properties and Water Quality in the Akarçay Stream (Turkey). Environ Manage 42:764. https://doi.org/10.1007/s00267-008-9165-8

Sitzia T, Campagnaro T, Kowarik I, Trentanovi G (2016) Using forest management to control invasive alien species: helping implement the new European regulation on invasive alien species. Biol Invasions 18:1-7. https://doi.org/ 10.1007/s10530-015-0999-8

SKEW (2009) Empfehlungen fuör den Anbau und Die Verwendung von Pflanz-Und Saatgut Einheimischer Wildpflanzen. Sekretariat SKEW

Taffetani F, Rismondo M (2009) Bioindicators system for the evalutation of the environment quality of agroecosystems. Fitosociologia 46:3-22

Tartari GA, Mosello R (1997) Metodologie analitiche e controlli di qualità nel laboratorio chimico dell'Istituto Italiano di Idrobiologia del Consiglio Nazionale delle Ricerche. Documento Ist Ital Idrobiol 60

Toniolo AR (1933) La zona delle risorgive nella Pianura Padana. Vie d'Italia, TCI, Milan

Ubaldi D (2008b) La vegetazione boschiva d'Italia: manuale di Fitosociologia Forestale. Clueb, Bologna

Ubaldi D (2008a) Le vegetazioni erbacee e gli arbusteti italiani, tipologie fitosociologiche ed ecologia. Aracne, Roma

Verde S, Assini S, Andreis C (2010) Le serie di vegetazione della regione Lombardia. In: Blasi C (ed) La vegetazione d'Italia. Palombi and Partner S.r.1, Roma, pp 181-203

Viaroli P, Rossetti G, Bertolini S, Pieri V, Venturelli G, Bernini F, Mozzanica E, Pedrelli A (2003) Qualità ambientale e problemi di conservazione dei fontanili nella pianura tra Piacenza e Parma. Studi Trent Sci Nat Acta Biol 80:181-183

Vilà M, Espinar JL, Hejda M, Hulme PE, Jarošík V, Maron JL, Pergl J, Schaffner U, Sun Y, Pyšek P (2011) Ecological impacts of invasive alien plants: a meta-analysis of their effects on species, communities and ecosystems. Ecol Lett 14:702-708. https://doi.org/10.1111/j.1461-0248.2011. 01628. $\mathrm{x}$

Vollenweider RA (1962) Sull'uso dei metodi conduttometrici per la titolazione dell'alcalinità totale, dei cloruri e dei solfati nelle acque dolci. Mem Ist Ital Idrobiol 15:29-42

van Wilgen B, Richardson D, Higgins S (2000) Integrated control of invasive alien plants in terrestrial ecosystems. In: Preston G, Brown G, van Wyk E (eds) Best management practices for preventing and controlling invasive alien species, symposium proceedings. The Working for Water Programme, Cape Town, pp 118-128

Publisher's Note Springer Nature remains neutral with regard to jurisdictional claims in published maps and institutional affiliations. 